\title{
EVALUASI PURNA HUNI DI PERUMAHAN CONDONGCATUR DITINJAU DARI ASPEK PENGGUNAAN DAN PERUBAHAN RUANG
}

\author{
Dita Ayu Rani Natalia*, Endah Tisnawati, Annisa Nurul Lazmi \\ Program Studi Arsitektur, Fakultas Sains dan Teknologi, Universitas Teknologi Yogyakarta, \\ Jl. Glagahsari No.63 Yogyakarta, 55164 \\ *ditayurani@uty.ac.id
}

\begin{abstract}
ABSTRAK. Perumahan merupakan hunian massal yang bersifat komoditi dengan bentuk bangunan yang tipikal dan dibangun untuk memenuhi kebutuhan hunian bagi masyarakat. Bangunan akan mengalami perubahan ketika tidak dapat memenuhi kebutuhan penghuni atau mengalami kerusakan. Proses atau cara yang digunakan oleh penghuni atau pengguna untuk melakukan perubahan pada bangunan untuk mencapai kenyamanan dan kebutuhan pengguna adalah berbeda-beda. Hubungan antara pengguna lingkungan hunian yang terbangun dengan perilaku penghuni tersebut menyebabkan adanya upaya evaluasi untuk mengetahui keterkaitan pengguna bangunan terhadap performa bangunan termasuk fasilitas dan fungsinya. Proses evaluasi untuk penggunaan bangunan dalam mencapai hal tersebut disebut dengan Evaluasi Pasca Huni (EPH). Penelitian ini bertujuan untuk mengidentifikasi aspek-aspek Evaluasi Purna Huni yang terjadi di Perumahan Condongcatur dari aspek Evaluasi Purna Huni yang terkait dengan penggunaan dan perubahan ruang. Metode penelitian yang digunakan adalah kualititaif dengan analisis Post Occupancy Evaluation (POE) atau Evaluasi Purna Huni (EPH). Hasil penelitian yang telah dilakukan menujukkan bahwa adanya perubahan fungsi pada bangunan sebagai ruang usaha maupun ruang lain. Acara komunitas juga mempengaruhi penggunaan dan perubahan ruang. Perubahan pada bangunan dilakukan secara horisontal maupun vertikal dengan adanya penambahan konstruksi. Faktor yang mempengaruhi penggunaan dan perubahan ruang disebabkan adanya perkembangan kawasan, kebutuhan ruang, penambahan anggota keluarga serta keamanan dan keselamatan bangunan.
\end{abstract}

Kata kunci: evaluasi purna huni, perumahan, ruang

ABSTRACT. Housing is a commodity mass residences that have a typical building and is built to meet residential needs for the community. Buildings will experience changes when they cannot meet the needs of residents or are damaged. The method used by residents or users to make changes to the building to achieve user comfort and needs are different. The relationship between the user of the residential built environment and the behavior of the occupants led to an evaluation effort to determine the relationship of building's users to the performance of the building including its facilities and functions. The evaluation process for building's use in achieving this is called the Post-Occupational Evaluation (EPH). This study aims to identify aspects of the Post-Occupational Evaluation that occur in Condongcatur Housing from the Post Evaluation aspect related to space use and change. The research method used is qualitative with the Post-Occupancy Evaluation (POE) analysis. The results of the research show that there is a change in the function of the building as a business space or other space. Community events also affect the use and replace the space. Changes in buildings are carried out horizontally and vertically with the addition of construction. Factors that influence the use and modification of space are due to the development of the area, space requirements, the acquisition of family members and the security and safety of buildings.

Keywords: post-occupational evaluation, housing, space

\section{PENDAHULUAN}

Kawasan perkotaan yang modern dan mewah mempengaruhi eksistensi karakter komunitas lama secara alami. Perkembangan ekonomi, sosial dan budaya yang berkembangan di kawasan perkotaan memberikan daya tarik bagi golongan menengah ke atas untuk tinggal di dalam pusat kota sehingga mengakibatkan peningkatan kebutuhan masyarakat terhadap lahan permukiman.
Pengembangan lahan akan terus terjadi dan akan berhadapan dengan berbagai bentuk penggunaan lahan seperti persawahan, hutan, perikanan dan lahan produktif lain yang kemudian berubah fungsi menjadi perumahan beserta infrastruktur yang membentuk suatu fungsi kawasan seperti fungsi kawasan permukiman, fasilitas umum dan fasilitas sosial, dan sebagainya. Kebutuhan lahan yang semakin meningkat mengakibatkan kawasan 
pinggiran yang berdekatan dengan pusat kota menjadi alternatif untuk kawasan hunian dengan harga lahan dan permukiman yang semakin tinggi dan menyebabkan daya beli masyarakat menengah ke bawah tidak terjangkau.

Usaha pemerintah dalam menangani permasalahan tersebut yaitu dengan membangun perumahan rakyat yang disebut dengan Perumahan Nasional (Perumnas). Perumnas merupakan salah satu badan milik pemerintah membangun perumahan dengan skala besar yang memberikan konstribusi signifikan dalam pembentukan kawasan permukiman dan kota baru yang tersebar di seluruh Indonesia. Tahun 1974, Perumnas mempunyai misi pada awal perkembangannya, yaitu membangun perumahan rakyat menengah ke bawah beserta sarana dan prasarananya.

Pemerintah membangun Perumnas pertama tahun 1978-1979 dan merupakan pilot project untuk pengembangan perumahan rakyat di Indonesia yang berlokasi di kawasan Condong Catur Yogyakarta. Pada awal pembangunan Perumahan Nasional (Perumnas) tahun 1978 diperuntukan untuk Pegawai Negeri Sipil (PNS) golongan I/II/III dan pegawai BUMN yang belum mempunyai rumah [1]

Perkembangan kawasan yang semakin pesat dan adanya perubahan kepemilikan mempengaruhi perubahan pada bangunan yang disebabkan oleh permasalahan bangunan pasca huni di Perumnas Condong Catur.

Menurut Budiharjo berdasarkan konsep perumahan masyarakat umum, perencanaan hunian untuk masyarakat menengah ke bawah harus memperhatikan aspek latar belakang penghuni akan kebutuhan tinggal di dalam lingkungan tersebut, kebutuhan dan kebiasaan fisik, ekonomi serta perilaku penghuni yang mempengaruhi tingkat kepuasan berhuni. [2]

Perubahan yang terjadi pada bangunan disebabkan karena adanya penyesuaian fungsi, kebutuhan untuk memenuhi kebutuhan penghuni dan peningkatan kualitas bangunan. Proses evaluasi untuk penggunaan bangunan dalam mencapai hal tersebut disebut dengan Evaluasi Pasca Huni (EPH) yang menekankan pada aspek arsitektur bangunan dan perilaku penghuninya. Rumusan permasalahan dari penelitian Evaluasi Purna Huni di Perumahan Condongcatur yaitu :
1. Bagaimana aspek Evaluasi Purna Huni mempengaruhi perubahan fisik dan fungsi bangunan di Perumahan Nasional Condong Catur?

2. Faktor-faktor apa sajakah yang berpengaruh dalam perubahan bangunan ditinjau dari proses Evaluasi Purna Huni?

Tujuan penelitian Kajian Evaluasi Purna Huni di Perumahan Condong Catur adalah untuk mengidentifikasi aspek-aspek Evaluasi Purna Huni yang terjadi di Perumahan Nasional Condong Catur dalam perubahan fisik dan fungsi bangunan dan menemukan faktor-faktor yang mempengaruhi perubahan bangunan yang ditinjau dari proses Evaluasi Purna Huni yang dilakukan oleh penghuni atau pengguna bangunan.

Manfaat penelitian ini bagi pengetahuan ilmu arsitektur terutama tentang Evaluasi Purna Huni adalah menambah tinjauan dan referensi dalam ranah teori mengenai kajian Evaluasi Purna Huni (EPH) terutama di perumahan yang mempunyai tipe yang sama dan pengembangan pada penelitian lanjutan berupa BPE (Building Performance Evaluation) yang mempengaruhi adaptasi bangunan ketika bangunan sudah tidak mampu untuk digunakan secara layak.

\section{Evaluasi Purna Huni}

Penelitian EPH menekankan tiga aspek yaitu aspek fungsional yang menyangkut aspek bangunan yang mendukung kegiatan, aspek teknis yang berkaitan dengan keamanan dan kenyamanan bangunan serta aspek perilaku yang berhubungan dengan penghuni dan lingkungan fisiknya.

Menurut Preiser dan Vischer, Building Performance Evaluation (BPE) atau evaluasi purna huni adalah pendekatan inovasi pada perancangan, desain, konstruksi dan hunian bangunan. Hal ini berdasarkan timbal balik dan evaluasi yang dilakukan pada setiap fase bangunan yang mencakup dari strategi perencanaan sampai hunian dan siklus bangunan. [3]. Evaluasi tersebut digunakan pada bangunan untuk melakukan perubahan dengan cara adaptive reuse atau recycling. Proses evaluasi ini dapat memberikan gambaran tentang fenomena yang mempengaruhi hubungan antara orang, proses dan lingkungan sekitar yang mencakup fisik, sosial dan lingkungan budaya. 


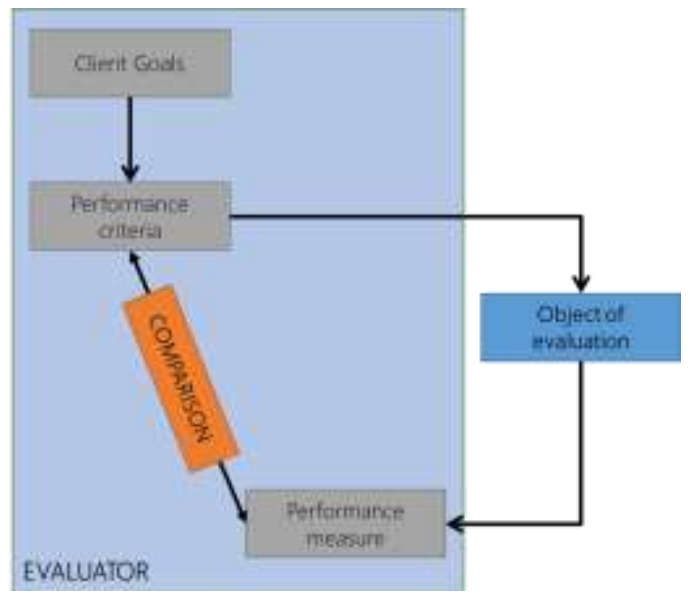

Gambar 1. Basic Feedback System

(Sumber: Architectural Research Consultants dalam Preiser dan Vischer, 2005)

Suryandhi dalam Elfajri menyatakan bahwa Evaluasi Pasca Huni merupakan kegiatan tingkat keberhasilan bangunan dalam memberikan kepuasan dan dukungan kepada penghuni terutama dalam pemenuhan kebutuhan-kebutuhannya. [4].

Kegiatan ini selain menilai kinerja bangunan selama dan pada saat dihuni juga untuk menilai tingkat ksesuaian antara bangunan dan lingkungan binaan dengan nilai-nilai dan kebutuhan penghuni bangunan, selain itu dapat memberikan manfaat dan masukan dalam merancang bangunan yang mempunyai fungsi yang sama. Evaluasi Purna Huni selain dapat meningkatkan kepuasan penghuni atas bangunan dan lingkungan binaan yang dihuni juga bermanfaat sebagai acuan jangka pendek, jangka menengah dan jangka panjang.

Dasar filosofi dan dasar teori dari EPH merupakan konsep dari performa bangunan yang mencakup aspek perilaku, kualitas dan saranan yang ada didalamnya yang diukur dan di evaluasi secara seksama [5] [6] [7] membagi EPH dalam tiga aspek, sebagai berikut:

\section{Aspek Fungsional}

Aspek fungsional yang dimaksud adalah menyangkut segala aspek bangunan (lingkungan binaan) yang secara langsung mendukung kegiatan pengguna atau pemakai dengan segal atributnya baik secara kelompok maupun individu. Pembentuk ruang seperti dinding, lantai dan langit-langit secara tidak langsung mempengaruhi kegiatan pengguna. Tata ruang dan sirkulasi juga mempengaruhi kegiatan pengguna dan terjadinya fungsi secara keseluruhan. Bangunan yang tidak efisien dapat disebabkan kekurang tepatan dalam proses perancangan yang menyebabkan pengguna tidak dapat melakukan adaptasi terhadap lingkungan binaan tersebut.

Permasalahan fungsional akan muncul dan menjadi titik perhatian evaluasi jika dalam perancangan bangunan yang menekan fungsi yang berpedoman pada kesesuaian antara area kegiatan dengan semua kegiatan yang terjadi didalamnya. Beberapa hal yang merupakan bagian kritirs dari aspek fungsional antara lain:

a. Pengelompokan fungsi menyangkut konsep pengelompokan dan pemisahan fungsi-fungsi yang berada dalam satu bangunan.

b. Sirkulasi merupakan salah satu hal yang penting pada fungsi bangunan. Kekurangtepatan perencanaan sirkulasi menyebabkan terdapat area yang "terlalu sepi" atau "terlalu padat", selain dalam beberapa kasus terjadi akibat perubahan organisasi yang mengakibatkan perubahan pola sirkulasi dan komunikasi kerja.

c. Faktor manusia yang menyangkut aspek perancangan dan standar yang berhubungan dengan kesesuaian konfigurasi, material dan ukuran terhadap penggunanya.

d. Fleksibilitas dan perubahan yang akan mempengaruhi fungsi.

2. Aspek Teknis

Kondisi fisik bangunan akan mempengaruhi pengguna atau pemilik dalam kenyamanan, keamanan bangunan dan mempunyai umur yang panjang. Hal tersebut berkaitan dengan kondisi bangunan meliputi stuktur, ventilasi, sanitasi dan pengaman bangunan serta sistem penyangganya.

3. Aspek Perilaku

Aspek perilaku berhubungan dengan kegiatan pengguna dengan lingkungan fisiknya. Evaluasi perilaku berkaitan dengan kesejahteraan sosial dan psikologis pemakai yang dipengaruhi oleh rancangan bangunan. Permasalahan perilaku yang perli diperhatikan seperti proximity dan teritoriality, privacy dan interaksi, persepsi, citra dan makna, kognisi dan orientasi. 


\section{Pembangunan Perumahan Nasional}

Pembangunan perumahan di Indonesia pada masa pemerintahan Hindia Belanda, diatur oleh lembaga bernama Van Verkeer en Waterstaat. Pada masa pemerintahan Jepang lembaga perumahan yang dikelola oleh Belanda kemudian dirubah menjadi Dobuko. Pasca kemerdekaan kemudian pengembangan perumahan dilaksanakan oleh Departemen Pekerjaan Umum. [8]. Perkembangan dan perjalanan Perum Perumnas sebagai penyedia rumah bagi masyarakat diubah menjadi Peraturan Pemerintah No. 12 Tahun 1988 dan disempurnakan melalui Peraturan Pemerintah No. 15 Tahun 2004 sebagai berikut [9] [10]:

1. Tahun 1974-1982. Perumnas memulai misi dalam membangun perumahan rakyat menengah ke bawah beserta sarana dan prasarananya.

2. Tahun 1983-1991. Perumnas mulai merintis pembangunan rumah susun sederhana untuk mendukung program peremajaan perkotaan.

3. Tahun 1992-1998. Perumnas membangun hampir $50 \%$ dari total pembangunan rumah nasional.

4. Tahun 1999-2007. Perumnas mengalami restrukturisasi pinjaman perusahan dan penurunan dalam capacity building karena dampak pasca krisis ekonomi.

5. Tahun 2008-2009. Perumnas mengalami kenaikan kinerja dalam mencapai target RKAP sebesar $300 \%$ daripada tahun sebelumnya.

6. Tahun 2010-2015. Pada periode ini Perumnas menjadi pelaku utama dalam rangka menuju National Housing \& Urban Corporation.

Pembangunan Perumahan nasional dalam skala besar ditanggani oleh Perumnas yang merupakan badan milik pemerintah. Konsep pengembangan skala besar dalam perumahan memberikan kontribusi yang signifikan pada Perumnas dalam pembentukan kawasan permukiman dan kota-kota baru yang tersebar di seluruh Indonesia. Perumnas memberikan multiplayer effect terhadap pembangunan wilayah di sekitarnya. Pengaruh tersebut menjadikan beberapa tempat yang dikembangkan menjadi "kota baru" yang befungsi menjadi penyangga kota yang strategis dan mempunyai investasi yang tinggi [8].

Tipe yang dibangun Perumnas merupakan tipe sederhana yang mempunyai luasan bangunan
$29 \mathrm{~m}^{2}$ dan $36 \mathrm{~m}^{2}$ dengan luas tanah minimal $90 \mathrm{~m}^{2}$ sehingga mempunyai tipe yang seragam. Karakteristik perumahan nasional secara umum yang dikembangan oleh Perumnas antara lain:

1. Luas tipe rumah seragam

2. Perumahan dengan skala masal

3. Tersedianya sarana dan prasarana perumahan yang dikembangkan bersama pemerintah.

4. Pengembangan perumahan dengan luas lahan yang besar dan merupakan lahan pemerintah atau BUMN

5. Perumahan untuk masyarakat menengah ke bawah [1]

\section{Rumah}

Menurut Undang-undang No. 1 tahun 2011 tentang Perumahan dan Kawasan Pemukiman menyatakan rumah adalah bangunan gedung yang berfungsi sebagai tempat tinggal yang layak huni, sarana pembinaan keluarga, cerminan harkat dan martabat penghuninya, serta aset bagi pemiliknya. [11]

Pengertian rumah menurut Turner dalam Osman \& Amin terdapat tiga hal yang melandasi dalam konsep "Housing is a Process" dalam "Freedom to Build" yaitu nilai rumah, fungsi ekonomi dan wewenang atas rumah. Turner menyatakan bahwa rumah bukan hanya sebagai hasil fisik tetapi merupakan suatu proses yang terus berkembang dan berkaitan dengan mobilitas sosial ekonomi penghuninya dalam kurun waktu tertentu. [12]

Fungsi rumah yang dinyatakan oleh Turner sangat berkaitan dengan tujuan yang ingin dicapai oleh penghuni. Turner dalam Osman\& Amin menyatakan terhadap hubungan antara perkembangan tingkat penghasilan dengan perkembangan kebutuhan manusia terhadap rumah. Teori yang dinyatakan oleh Turner berkaitan dengan adanya kondisi ekonomi dengan skala prioritas kebutuhan hidup dan prioritas kebutuhan perumahan. [12]

Ada tiga fungsi utama sebagai tempat bermukim, sebagai berikut:

1. Rumah sebagai penunjang identitas keluarga yang berkaitan dengan kualitas hunian atau perlindungan yang diberikan oleh rumah.

2. Rumah sebagai penunjang kesempatan keluarga untuk berkembang dalam 
kehidupan sosial, budaya dan ekonomi dimana lokasi rumah tersebut didirikan.

3. Rumah sebagai penunjang rasa aman yang mempunyai pengertian terjaminnya keadaan keluarga di masa depan setelah mendapatkan rumah. Jaminan keamanan atas lingkungan perumahan yang ditempati berupa kepemilikan dan lahan [13].

\section{METODE PENELITIAN}

Metode yang digunakan dalam penelitian ini adalah metoda deduktif kualitatif dengan analisis Post Occupancy Evaluation (POE) atau Evaluasi Purna Huni (EPH). Menurut Prisier, Rabinowist, dan White [5] menyatakan bahwa analisis POE atau EPH adalah suatu proses mengevaluasi bangunan secara sistematis dan tepat setelah bangunan tersebut dibangun dan ditempati sekian waktu lamanya. Pada proses evaluasi ini, peneliti boleh mengangkat beberapa permasalahn tertentu tergantung keinginan dan kebutuhan peneliti terhadap suatu masalah yang ingin peneliti dalami.

Pengukuran variabel dalam penelitian dapat diukur dengan indikator dan parameter yang disusun sesuai aspek penelitian. Variabel penelitian dibagi menjadi variabel dependen atau variabel terikat merupakan variabel yang dipengaruhi atau menjadi akibat karena adanya variabel bebas, sedangkan variabel independen atau variabel bebas merupakan variabel yang mempengaruhi atau yang menjadikan sebab perubahan atau timbulnya variabel dependen (terikat). Variabel terikat pada penelitian ini adalah perubahan tatanan ruang, perubahan fungsi bangunan, dan perubahan ukuran. Variabel bebas pada penelitian EPH yaitu faktor ekonomi, sosial budaya, lingkungan, lokasi dan kondisi fisik bangunan.

Teknik pengambilan sampel/responden yang digunakan adalah purposive sampling, yaitu teknik pengambilan sampel tidak secara acak melainkan berdasarkan pertimbangan tertentu atau sengaja. Pengambilan sampel berdasarkan data sekunder yang diperoleh dari kantor Perumnas dan instansi terkait yang meliputi sejarah dan kondisi lingkungan di Perumnas yang kemudian dijadikan dasar dalam pengambilan sampel penelitian dengan melakukan identifikasi populasi. Data populasi yang diperoleh kemudian menjadi dasar dalam melakukan observasi bangunan yang meliputi kriteria perubahan fisik ringan, sedang dan perubahan total.

Penelitian terbagi atas beberapa tahapan, diantaranya yaitu :

1. Tahap Persiapan. Pada tahap ini, yang dilakukan adalah memantapkan kerangka penelitian dan mempersiapkan kegiatan pengumpulan data.

2. Tahap Pengumpulan Data. Tahapan ini dibagi menjadi 2 kegiatan yaitu Sekunder, pada tahap ini melakukan kajian pustaka untuk menghasilkan landasan teori yang akan digunakan untuk melakukan observasi lapangan. Sedangkan pada kegiatan Primer dilakukan pengumpulan data lapangan melalui observasi yang meliputi pengamatan, kuisioner, interview dan dokumentasi.

3. Tahap Interpretasi Data dan Analisa. Pada tahapan ini data primer dan sekunder yang terkumpul kemudian di analisa dalam beberapa tahap antara lain periode waktu perubahan, pengecekan data dengan teknik triagulasi dan mendeskripsikan dengan prosentase yang terjadi pada sampel bangunan.

4. Tahap Generalisasi dan Penyimpulan Hasil Penelitian. Pada tahap ini dilakukan kajian berulang antara tema dan kategori yang muncul dari tahap analisis.

5. Tahap Diseminasi. Pada tahap ini dilakukan diskusi dalam konteks kajian evaluasi purna huni dan faktor yang mempengaruhinya dalam perubahan bangunan oleh penghuni atau pengguna.

\section{HASIL DAN PEMBAHASAN}

\section{Perubahan Fisik Lingkungan dan Bangunan}

Perumahan Condongcatur terletak di Kecamatan Depok, Kelurahan Condongcatur Kabupaten Sleman. Perumahan ini terbagi menjadi tiga padukuhan yaitu dusun Dero, Gempol dan Ngringin. Batas wilayah perumahan pada sisi utara adalah Jalan Tanjung dan Jalan Bakung, sisi selatan adalah Ringroad Utara, sisi timur adalah Jalan Nusa Indah dan sisi barat adalah Jalan Cempaka.

Kawasan Perumahan Condongcatur terdiri dari 3 Rukun Warga dengan jumlah Rukun Tangga sebanyak 28 . Secara rinci pembagian wilayah di Perumahan Condongcatur sebagai berikut:

1. Dusun Gempol RW 13 terdiri dari $10 \mathrm{RT}$ 
2. Dusun Dero RW 17 terdiri dari $8 \mathrm{RT}$

3. Dusun Ngringin RW 22 terdiri dari 10 RT



Gambar 2. Lokasi Penelitian

(Sumber: Observasi Lapangan, 2018)

Bangunan rumah Perumahan menggunakan material asbes untuk dinding, jendela dan pintu menggunakan rangka alumunium dengan struktur bangunan menggunakan baja. Lebar jalan pada awal perencanaan yaitu 1,5 $\mathrm{m}$ dan 1,5 $\mathrm{m}$ digunakan sebagai taman, hanya kondisi sekarang taman sudah dihilangkan karena digunakan sebagai pelebaran jalan, sedangkan jalan utama mempunyai lebar $7 \mathrm{~m}$.

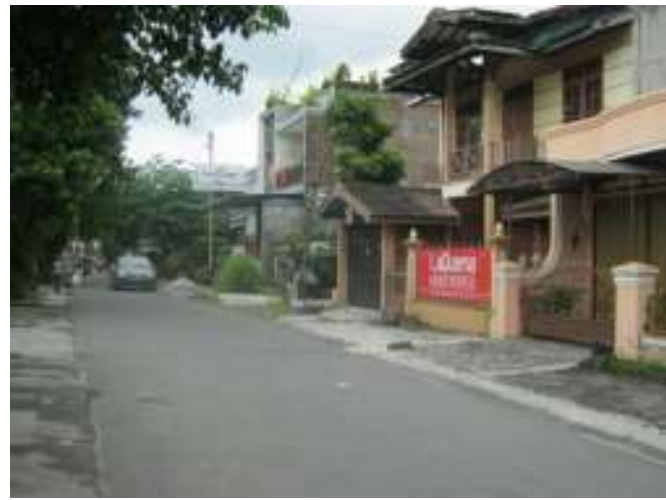

Gambar 3. Jalan Utama di Perumahan Condongcatur

(Sumber: Observasi Lapangan, 2018)

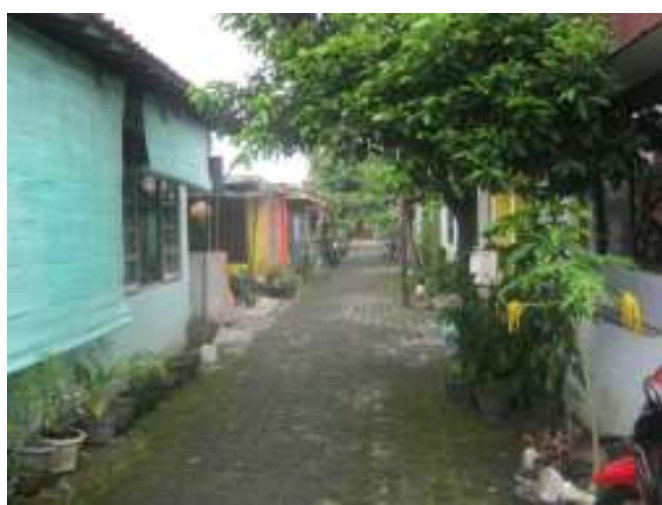

Gambar 4. Kondisi Jalan Lingkungan (Sumber: Observasi Lapangan, 2018)

Perumahan Condongcatur pada awal pembangunan hanya mempunyai satu tipe ukuran rumah yaitu tipe 36 dengan luas tanah kurang lebih $96 \mathrm{~m}^{2}$. Rumah tersebut terdiri dari ruang tamu sekaligus ruang keluarga, 2 ruang tidur, ruang makan, kamar mandi dan dapur.



Gambar 5. Denah Rumah Awal di Perumahan Condongcatur

(Sumber: Perum Perumnas, 2018)

Pada tahun 1978 menurut data Perum Perumnas terdapat 1.213 unit rumah dan 16 kios dengan rincian di RW 13 terdapat 348 unit rumah, RW 17 terdapat 412 unit rumah dan RW 20 terdapat 454 unit rumah dan 16 kios.Pada tahun 2014 terdapat penambahan 20 unit rumah sehingga total bangunan menjadi 1.249 rumah dengan penambangan pada area kosong yang akan digunakan sebagai pengembangan unit rumah.

Pada perkembangannya Perumahan Condongcatur telah mengalami perubahan baik perubahan ringan, sedang maupun total. Perubahan bangunan dipengaruhi oleh adanya penyesuaian fungsi, kebutuhan untuk memenuhi kebutuhan penghuni dan 
peningkatan kualitas bangunan sehingga bangunan dapat digunakan secara optimal. Hal yang dilakukan dalam perubahan bangunan antara lain melakukan perbaikan, perluasan, penambahan, perubahan fungsi atau melakukan perubahan total bangunan. pembagian kategori perubahan bangunan secara fisik dilakukan berdasarkan pengataman di lapangan dan penentuan skala perubahan. Kategori perubahan ringan pada bangunan didasarkan pada perubahan fisik bangunan yang minimal atau sedikit dari bangunan aslinya sehingga tidak mempengararuhi tampilan bangunan. Perubahan sedang pada bangunan didasarkan pada perubahan material bangunan yang digunakan sehingga mempengaruhi tampilan bangunan. Perubahan total pada bangunan adalah perubahan yang terjadi pada keseluruhan bangunan sehing tampilan baru berbeda dengan tampilan aslinya. Hal ini juga dipengaruhi oleh penggantian material dan penambahan konstruksi baik secara vertikal maupun horisontal.

Pada perubahan ringan bangunan masih menggunkan material asli seperti asbes dengan jendela dari alumunium dengan penmbahan kanopi untuk memenuhi kebutuhan pemilik atau pengguna. Penambahan tersebut tidak mengubah tampilan bangunan secara keseluruhan dan masih mempertahankan tampilan bangunan asli. Pada perubahan bangunan sedang bangunan telah mengalami perubahan baik secara material tetapi bangunan asli masih dapat dilihat dari tampilan fasad bangunan. perubahan material antara lain perubahan dinding dari gypsum menjadi dinding bata atau batako. Perubahan bangunan disebabkan oleh adanya kebutuhan antara lain menjadi tempat usaha ataupun yang lainnya. Pada perubahan total bangunan eksisting mengalami perubahan total baik dari tampilan maupun struktur bangunan. Pada beberapa bangunan sebagian besar bangunan dihancurkan kemudian didirikan bangunan dengan kontruksi baru.

Pemilihan 45 sampel bangunan didasarkan pada data hasil identifikasi perubahan fisik bangunan dengan mengambil 5 sampel pada masing-masing RW. Pengambilan sampe tersebut didasarkan pada:

1. Lokasi rumah dengan jalan utama dan gang yang berkaitan dengan kemudahan pencapaian dan lebar jalan

2. Letak rumah yang berada pada posisi hook atau ditengah deretan perumahan.
Perubahan bangunan di Perumahan Condongcatur didominasi oleh perubahan total dengan prosentase $44,35 \%$ dari 1.249 rumah. Sedangkan bangunan yang mengalami perubahan sedang sebesar $40,14 \%$ dan perubahan ringan sebesar $15,77 \%$. Pada bangunan eksisting, peruahan merata pada tiap RW dengan dominasi perubahan total. Unit bangunan yang dominan mengalami perubahan terdapat di RW 22 dengan 215 unit. Secara rinci jumlah perubahan fisik bangunan berdasarkan klasifikasi bangunan dari hasil observasi lapangan dapat dilihat pada tabel 1 di bawah ini.

Tabel 1. Jumlah Perubahan Fisik Bangunan di Perumahan Condongcatur Tahun 2018

\begin{tabular}{lccccc}
\hline Perubahan & RW & RW & RW & Total & $\%$ \\
\hline Ringan & 68 & 66 & 63 & 197 & 15.77 \\
Sedang & 135 & 168 & 196 & 499 & 40.14 \\
$\begin{array}{l}\text { Total } \\
\text { Lahan }\end{array}$ & 145 & 192 & 215 & 551 & 44.35 \\
$\begin{array}{l}\text { Kosong/ } \\
\begin{array}{l}\text { Bekas } \\
\text { Bongkaran }\end{array}\end{array}$ & 0 & 0 & 1 & 2 & 0.14 \\
$\begin{array}{l}\text { Total } \\
\text { Bangunan }\end{array}$ & $\mathbf{3 4 8}$ & $\mathbf{4 2 6}$ & $\mathbf{4 7 5}$ & $\mathbf{1 2 4 9}$ & $\mathbf{1 0 0}$ \\
\hline $\begin{array}{l}\text { Sumber: Observasi Lapangan, 2018 } \\
\text { Sumber }\end{array}$ & & & &
\end{tabular}

Ketinggian bangunan berkaitan dengan perubahan fisik bangunan yang dilakukan oleh pemilik atau penghuni. Perubahan bangunan tidak hanya secara horisontal tetapi juga secara vertikal. Dalam sampel di perumnas Condongcatur perubahan secara horisontal bangunan eksisting yang merupakan bangunan 1 lantai. Kebutuhan keluarga penghuni yang semakin meningkat seiring waktu menjadi faktor bangunan mengalami perubahan ketinggian lantai.

Bangunan di perumahan Condongcatur yang memiliki ketinggian 1 lantai memiliki prosentasi yang tinggi mencapai $72.94 \%$ atau 911 rumah dari 1249 rumah yang ada di perumnas Condongcatur. Untuk RW 17 didominasi bangunan dengan ketinggian 1 lantai sebanyak 330 rumah. Sedangkan untuk ketinggian bangunan 3 lantai memiliki jumlah prosentase sebesar $1.12 \%$ dari total 14 rumah yang yang terdapat di $3 \mathrm{RW}$. Secara rinci jumlah perubahan fisik bangunan berdasarkan ketinggian bangunan dari hasil observasi lapangan dapat dilihat pada tabel 2 di bawah ini. 
Tabel 2. Jumlah Ketinggian Bangunan di Perumahan Condongcatur Tahun 2018

\begin{tabular}{lccccc}
\hline Ketinggian & RW & RW & RW & Total & $\%$ \\
\hline 1 Lantai & 287 & 330 & 294 & 911 & 72.94 \\
2 Lantai & 60 & 85 & 179 & 324 & 25.94 \\
3 Lantai & 1 & 11 & 2 & 14 & 1.12 \\
\hline $\begin{array}{l}\text { Total } \\
\text { Bangunan }\end{array}$ & $\mathbf{3 4 8}$ & $\mathbf{4 2 6}$ & $\mathbf{4 7 5}$ & $\mathbf{1 2 4 9}$ & $\mathbf{1 0 0}$ \\
\hline
\end{tabular}

Sumber: Observasi Lapangan, 2018

Pada perumahan Condongcatur terdapat 196 bangunan yang telah mengalami perubahan fungsi selain tempat tinggal. Fungsi dominan selain rumah tinggal adalah usaha perdagangan, termasuk rumah toko dan warung. Untuk persebaran fungsi dari usaha dagangnya sendiri pada area yang berdekatan dengan jalan utama. Sedangkan untuk tipe fungsi usaha yang melayani skala lebih kecil seperti warung klontong banyak ditemui di gang. Fungsi yang dominan lainya adalah jasa dengan total 61 unit diantarannya laundry, usaha fotokopi, bengkel dan usaha lainya yang sebagian merupakan pendukung kawasan sekitar. Secara detail jumlah bangunan berdasarkan fungsinya dapat dilihat pada tabel 3 di bawah ini.

Tabel 3. Jumlah Bangunan di Perumahan Condongcatur berdasarkan Fungsinya Tahun 2018

\begin{tabular}{clc}
\hline No & \multicolumn{1}{c}{$\begin{array}{c}\text { Fungsi } \\
\text { Bangunan }\end{array}$} & Jumlah \\
\hline 1 & Toko & 14 \\
2 & Usaha & 86 \\
3 & Perdagangan & 61 \\
4 & Jasa & 5 \\
5 & Kesehatan & 4 \\
6 & Tempat & 2 \\
7 & Penginapan & 24 \\
8 & Tempat Kos & 4 \\
9 & Keagamaan & Rumah Tinggal \\
\hline Sumber: Observasi Lapangan, 2018
\end{tabular}

\section{Penggunaan dan Perubahan Ruang}

Perubahan dan penambahkan bangunan disebabkan oleh beberapa faktor fisik dan juga non fisik. Keinginan seorang pemilik atau pengguna bangunan untuk menggunakan bangunan secara optimal dan maksimal menjadi salah satu penyebab dalam perubahan fungsi bangunan. Bentuk perubahan bangunan juga dapat disebabkan oleh fungsi yang berubah atau bertambah, misalnya bangunan yang awalnya merupakan rumah tinggal, bertambah atau berubah menjadi fungsi pedagang dan jasa dengan membuka warung ataupun usaha yang lain. Perubahan fungsi ini mempengaruhi pengguna ruang, dimana awalnya ruang yang digunakan untuk ruang tamu beralih fungsi menjadi ruang untuk usaha.

Berdasarkan hasil observasi lapangan dari 45 sampel unit bangunan terdapat 13 unit bangunan yang telah mengalami perubahan fungsi bangunan. Perubahan tersebut mempengaruhi penggunaan dan perubahan ruang pada bangunan eksisiting. Perubahan fungsi bangunan di dominasi oleh kegiatan perdagangan dan jasa yang dapat dilihat pada tabel 4 di bawah ini.

Tabel 4. Perubahan dan/atau Penambahan Fungsi Bangunan di Perumahan Condongcatur

\begin{tabular}{|c|c|c|}
\hline No & Pemilik & Fungsi Bangunan \\
\hline 1 & Asta F & Rumah tinggal dan kos-kosan \\
\hline 2 & Eko A & Kontrakan \\
\hline 3 & Dyaning $\mathrm{P}$ & $\begin{array}{l}\text { Rumah tinggal dan tempat } \\
\text { usaha }\end{array}$ \\
\hline 4 & Ibu Marwati & Rumah tinggal dan warung \\
\hline 5 & Ibu Ellen & $\begin{array}{l}\text { Rumah tinggal dan tempat } \\
\text { usaha }\end{array}$ \\
\hline 6 & Harsoyo & Rumah tinggal dan warung \\
\hline 7 & Tri Mulyani & $\begin{array}{l}\text { Rumah tinggal dan tempat } \\
\text { usaha }\end{array}$ \\
\hline 8 & $\begin{array}{l}\text { Bapak } \\
\text { Khoirunudin }\end{array}$ & $\begin{array}{l}\text { Rumah tinggal dan tempat } \\
\text { usaha lainnya }\end{array}$ \\
\hline 9 & Ibu Kristina & $\begin{array}{l}\text { Rumah tinggal dan tempat } \\
\text { usaha }\end{array}$ \\
\hline 10 & $\begin{array}{l}\text { Ibu } \\
\text { Samingan }\end{array}$ & Rumah tinggal dan warung \\
\hline 11 & lqbal & $\begin{array}{l}\text { Kantor, tempat usaha dan kos- } \\
\text { kosan }\end{array}$ \\
\hline 12 & Atun & Rumah tinggal dan warung \\
\hline 13 & $\begin{array}{l}\text { Ibu } \\
\text { Suhartinah }\end{array}$ & Rumah tinggal dan warung \\
\hline 14 & $\begin{array}{l}\text { Ibu } \\
\text { Ngadiyem }\end{array}$ & Rumah tinggal dan kos-kosan \\
\hline
\end{tabular}

Bangunan yang mengalami perubahan fungsi sebagian besar mempengaruhi perubahan pada layout ruang yang digunakan. Perubahan tersebut terjadi karena adanya penggunaan ruang yang digunakan bersama maupun adanya penambahan ruang yang digunakan. Perubahan fungsi bangunan yang mempengaruhi perubahan penataan ruang dapat dibedakan menjadi 3 tipe, yaitu:

1. Tipe 1: fungsi bangunan mengalami perubahan pada bangunan inti dengan adanya penambahan ruang usaha yang terdapat dalam rumah inti. 
2. Tipe 2: penambahan ruang usaha yang letaknya terpisah dari bangunan inti.

3. Tipe 3: perubahan total pada fungsi bangunan eksisting menjadi tempat usaha.

Penggunaan dan perubahan ruang juga dipengaruhi oleh acara komunitas maupun keluarga. Kegiatan yang dilakukan di perumahan antara lain arisan, kebaktian keluarga, dasawisma, PKK, pengajian haji, acara lebaran dan pengajian. Berdasarkan hasil observasi lapangan sebagian besar penggunaan ruang menggunakan ruang tamu dan keluarga sebagai ruang bersama. Perubahaan penggunaan ruang untuk acara dapat dikategorikan menjadi 3 tipe yaitu:

1. Tipe 1: penggunaan ruang semi privat dan semi publik sebagai ruang bersama

2. Tipe 2: penggunaan ruang semi publik dan publik sebagai ruang bersama

3. Tipe 3: penggunaan ruang semi privat, semi publik dan publik sebagai ruang bersama.

Perubahan dan penambahan ruang menyebabkan adanya perubahan pada ukuran yang dilakukan dengan perluasan dan/atau pnambahan secara horisontal dan vertikal. Perubahan bangunan secara horisontal dengan melakukan perluasan pada area samping, belakang, dan depan bahkan pada keseluruhan area lahan. Perluasan ini dilakukan untuk dapat mengoptimalkan penggunaan ruang yang dilakukan oleh penghuni. Penambahan yang dilakukan antara lain penambahan ruang teras, ruang tamu, garasi, kamar dan lain sebagainya. Pada pengembangan secara vertikal akibat adanya penambangan ruang menyebabkan konstruksi bangunan mengalami penambahan dan perubahan ataupun melakukan pembongkaran total dan kemudian dibangun ulang. Penambahan ruang secara vertikal dapat dikategorikan menjadi 3 tipe yaitu:

1. Tipe 1: penambahan ruang di lantai 2 dengan menambahkan konstruksi struktur pada bangunan eksisting

2. Tipe 2: bangunan eksisiting tidak mengalami perubahan secara struktur. Bangunan baru berada di sisi samping maupun belakang bangunan eksisting. Pada perkembangannya bangunan eksistng mengalami perubahan material bahan bangunan.

3. Tipe 3: bangunan eksisting mengalami perubahan total dengan penggantian konstruksi struktur dan material bangunan. bangunan dikembangkan dengan memaksimalkan luas lahan yang ada.

Penggunaan dan perubahan ruang di perumahan Condongcatur dipengaruhi faktor eksternal dan internal. Faktor eksternal yang mempengaruhi perubahan tersebut antaral lain perkembangan kawasan di sekitar perumahan. Kawasan sekitar mengalami perubahan pesat dengan adanya pembangunan jalan Ringroad serta berdirinya kawasan pendidikan berupa sekolah tinggi yang menyebabkan pertumbuhan perdagangan dan jasa. Faktor tesebut mempengaruhi penghuni atau pemilik ruamh untuk melakukan perubahan pada bangunan. perubahan tersebut dipengaruhi faktor ekonomi untuk meningkatkan penghasilan.

Pengaruh internal pemilik atau pengguna bangunan melakukan perubahan bangunan antara lain:

1. Menambah penghasilan

2. Bertambangnya anggota keluarga

3. Mempunyai kendaraan atau adanya penambahan kendaraan

4. Kebutuhan ruang yang lebih luas

5. Adanya acara komunitas

6. Faktor keamanan dan keselamatan bangunan karena bangunan telah mengalami kerusakan

\section{KESIMPULAN}

Perumahan merupakan hunian massal yang bersifat komoditi dengan bentuk bangunan yang tipikal dan dibangun untuk memenuhi kebutuhan hunian bagi masyarakat. Unit bangunan yang mempunyai tipe yang sama dalam perkembanganya mengalami perubahan ruang akibat adanya kebutuhan pengguna. Proses evaluasi untuk penggunaan bangunan dalam mencapai kenyamanan dan kebutuhan pengguna disebut dengan Evaluasi Pasca Huni (EPH) yang menekankan pada aspek arsitektur bangunan dan perilaku penghuninya. Berdasarkan hasil penelitian perubahan yang dilakukan oleh penghuni antara lain perubahan fungsi pada bangunan yang mempengaruhi pengguna ruang, dimana awalnya ruang yang digunakan untuk ruang tamu beralih fungsi menjadi ruang untuk usaha maupun ruang lain.

Penggunaan ruang untuk acara komunitas atau keluarga juga mempengaruhi perubahan ruang yang digunakan untuk kegiatan 
bersama. Perubahan pada bangunan dilakukan dengan pengembangan secara horisontal maupun vertikal dengan penambahan konstruksi struktur bangunan. Penggunaan dan perubahan ruang yang terjadi di perumahan Condongcatur juga dipengaruhi oleh adanya kebutuhan penguni untuk memaksimalkan penggunaan dan fungsi ruang yang dipengaruhi oleh faktor eksternal dan internal. Faktor eksternal yang berpengaruh adalah perkembangan kawasan yang semakin berkembang pesat menjadi kawasan pendidikan dan perdagangan jasa. Pada faktor internal yang mempengaruhi perubahan dan bangunan adalah adanya kebutuhan pengguna akan ruang yang lebih luas, penambahan anggota baru dalam keluarga, adanya kendaraan, acara komunitas dan keamanan serta keselamatan bangunan.

\section{UCAPAN TERIMA KASIH}

Penelitian ini dibiayai oleh Direktorat Riset dan Pengabdian Masyarakat Direktorat Jenderal Penguatan Riset dan Pengembangan Kementerian Riset, Teknologi dan Pendidikan Tinggi Tahun 2018

\section{DAFTAR PUSTAKA}

[1] Natalia, Dita Ayu Rani. (2015). Tesis: Adaptasi Bangunan di Perumnas Condongcatur Sleman DIY. Universitas Gadjah Mada. Yogyakarta

[2] Budihardjo, Eko. (2006). Sejumlah Masalah Permukiman Kota. Bandung: Alumni.

[3] Preiser, V.F.E. \& Vischer, Jacqueline C. (2005). Assessing Buidling Performance. Elsevier ButterworthHeinemann. Burlington, MA

[4] Elfajri, Irhami. (2016). Tesis: Evaluasi Pasca Huni Ruang Perawatan Intensif RS PKU Muhammadiyah Yogyakarta $\begin{array}{llll}\text { Unit II. } & \text { Program Studi Magister }\end{array}$ Manajemen Rumah Sakit. Universitas Muhammadiyah Yogyakarta

[5] Preiser, V.F.E., Rabinowitz, H.Z., White, ET. (1988). "Post Occupancy Evaluation". New York : Van Nostrand Ranhola Company.

[6] Syafriyani, Sangkertadi\& Waani, Judy O. (2015). Evaluasi Purna Huni (EPH): Aspek Perilaku Ruang dalam SLB YPAC Manado. Jurnal Media Matrasain Vol. 12 No.3. Hal. 1-13
[7] Sudibyo, S. (1989). Aspek Fungsi dan Teknis Post Occupancy Evaluation dan Beberapa Metodologi Penelitian. Universitas Trisakti. Jakarta

[8] Perumnas. (2013). Perumnas, Hingga Kini Perannya Tak Tergantikan. Rumah Kita Buletin Perumnas. Pp. 8-9

[9] Peraturan Pemerintah No. 12 Tahun 1988. Perusahaan Umum (Perum) Pembangunan Perumahan Nasional

[10] Peraturan Pemerintah No. 15 Tahun 2004. Perusahaan Umum (Perum) Pembangunan Perumahan Nasional

[11] Undang-undang No. 1 tahun 2011. Perumahan dan Kawasan Pemukiman

[12] Osman, Wiwik Wadinah dan Amin, Samsuddin. (2012). Rumah Produktif: Sebagai Tempat Tinggal dan Tempat Bekeria di Permukiman Komunitas Pengrajin Emas (Pola Pemanfaatan Ruang pada Usaha Rumah Tangga). Prosiding 2012 Hasil Penelitian Fakultas Teknik Vol 6

[13] Tazrief. (2013). Pengembangan Wilayah. https://www.scribd.com/doc/153659170/ Pengembangan-Wilayah 